\title{
Europe's next big battle must be won
}

Preparations for Europe's next big battle in 1996 have begun with too much public speaking in France and Germany, and too little concern for the kind of agenda that will make a constructive intergovernmental conference.

WHILE Europe still echoes to the noise of the political battles over the Maastricht Treaty a year ago, the drum-beat warning of the next great confrontation can be heard. Last week, Europe's two heavyweights, Chancellor Helmut Kohl of Germany and M. Edouard Balladur, the prime minister of France, declared themselves on the future of Europe as they see it. Each affirmed the importance of the close understanding between Germany and France that has been the inspiration of the European Community (now the European Union, EU) since the beginning.

Both Kohl and Balladur last week also offered a vision of a Europe fashioned on hierarchical lines, with France and Germany at the centre, or at the top. But otherwise the two visions of Europe are very different. Chancellor Kohl wants the EU to take Central Europe under its wing. M. Balladur is less enthusiastic about that objective, but also uneasy at the pace of integration within the EU on which its federalist members have set their hearts. Both men face elections in the next half year; Kohl in November, while France must hold a presidential election in the spring.

The importance of these developments does not lie simply in the content of what was said last week, but in the decision taken at the end of 1992 that in 1996 there will be another intergovernmental conference (of the kind that gave rise to the Maastricht Treaty) to reach agreement on "ever closer union" in matters of foreign policy and defence. Understandably, Kohl and Balladur will be asked to say what their opinions are on these European issues at the elections ahead of them. They may also have calculated that they can only benefit themselves if they stake their claim on the agenda of the 1996 conference well in advance.

But they are mistaken. The truth about the EU is that if it does not hang together, it will fall apart. Indeed, four years ago, one of the arguments for the 1996 conference was that, without some timetable for closer union, the momentum that Maastricht was supposed to generate would be lost. (The more compelling argument for a conference then is that Europe must work out some way of dealing with matters such as that of the republics of ex-Yugoslavia, which on present form could still be a burning issue in 1996.) What has gone wrong is simply that Maastricht failed to generate noticeable momentum of a unifying character. Most member states were politically enervated by the battle over ratification. Even now, with recession still in the air, there is little sense that the battles were worthwhile.

That is why the agenda for the next conference should be more carefully prepared than that over which people quarrelled at Maastricht. The impatience of the federalists notwithstanding, the most urgent need is for a modest agenda, but one that is widely discussed in public well in advance. There needs, for example, to be a European policy on immigration, given that residents in one member state can choose to live in another. There needs to be a common policy on Central Europe that overrides competition between EU states for special influence, but which commands general respect. There needs to be a common policy on defence procurement, on which most European governments remain old-fashioned and chauvinistic. And it is high time that the EU dusted off its traditional regime for the regulation of internal trade in nuclear materials, given that next year's review conference of the Non-Proliferation Treaty will (or should) require more vigilance of all its members. That should be enough to keep heads of government occupied for a couple of days, the standard time allocation.

Meanwhile, there is much of a general character that should persuade Kohl and Balladur to rein in speculation about a hierarchical Europe of the kind they advertised last week. The most important consideration is that there may by 1996 be four new members of the EU (Austria, Finland, Norway and Sweden), which can be rushed into new grand designs only at the risk of disillusion. By then, with the recession perhaps finally over, it may also have become apparent that the EU is not the naturally prosperous place its founding fathers imagined it must be, but a place in which unemployment is unacceptably too prevalent and overall prosperity is disappointing. In other words, by 1996, it may well be apparent to Europe's taxpayers that the economic miracle the EU was supposed to engender is still a long way off. Talk of "core" membership will accentuate that impression, with disastrous results.

\section{Blaming somebody else}

Japan needs better arrangements for conducting clinical trials of new therapeutic drugs.

JAPAN's Ministry of Health and Welfare is treading in the familiar path of bureaucracies faced with calamity within their sphere of responsibility: blame somebody, indeed anybody, else. That is what happened last week, when the ministry penalized Nippon Shoji, the Osaka drug manufac- 